\title{
Students' Attitudes Towards Literature Use and its Effects on Vocabulary Learning
}

\author{
Elif Karakaya \\ British Town Language Schools, Kutahya \\ Alipasa Neighbourhood, Beyzade Street, 43100 Kutahya, Turkey \\ Tel: +90555-832-90-71 E-mail: elifkarakaya1503@gmail.com \\ Ayhan Kahraman (Corresponding author) \\ The Faculty of Arts and Sciences, Dumlupinar University \\ Central Campus, 43100 Kutahya, Turkey \\ Tel: +90505-726-22-77 E-mail: ayhan@dumlupinar.edu.tr
}

Received: 14-05-2013

doi:10.7575/aiac.ijalel.v.2n.5p.155
Accepted: 30-06-2013

Published: 01-09-2013

\begin{abstract}
Although language teachers are aware of the benefits of using literature in language classrooms in theory, they do not use it "consciously" practically. For this reason, the purpose of the present paper is to "re-highlight" the use of literature in language classrooms and make teachers use it "consciously" in classes. Wherefore, this study was conducted in $2010-$ 2011 education year, at a private language school in Turkey by the participation of 14 students having A2 level English proficiency. Data collection of the study was twofold as descriptive and experimental. The descriptive part was made of an attitude questionnaire towards the use of literature, namely theatrical plays, in language classrooms. The experimental part was conducted in ten-week period. There were two groups as one experimental group which had equal students. While the students of the control group had the lessons of the traditional curriculum of the private language school, the students of the experimental group had the literature, specially theatrical plays, integrated lessons together with the traditional curriculum of the private language school. A vocabulary test was applied to both groups to figure out the vocabulary learning levels of the students. The findings of the attitude questionnaires and vocabulary tests were analyzed by SPSS programme. It was found that there were positive attitudes towards literature integrated lessons and that the use of literature affected students' vocabulary levels. The findings of the present study may be useful for language teachers, text book writers, syllabus designers and language learners.
\end{abstract}

Keywords: literature, language teaching, attitude, theatrical plays, vocabulary learning

\section{Introduction}

Today's global world forces people to learn another language apart from their mother language. Therefore, the language teaching field has always been exposed to new approaches, methods and techniques through the time. Using literature in language classes has been one of the important issues in many books (eg. Brumfit \& Carter, 1986; Collie \& Slater, 1987; Lazar, 1993), articles or opinion papers (eg. Hismanoglu, 2005; Turker, 1991). Researchers and ELT scholars such as Henry Widdowson (1984), Joanne Collie and Stephen Slater (1987), Alan Maley and Alan Duff (1989), Michael Long and Ronald Carter (1991), Christopher Brumfit and Ronald Carter (2000) have argued that literature, as well as being a motivational valuable authentic material, helps to the students' linguistic development, personal development and cultural enrichment (Carter \& Long, 1991; Collie \& Slater, 1987). Language teachers, course book writers, syllabus designers are aware of this truth, but the practice does not show the reality. Sadly, most of language teachers are content with course books. On the first page of almost all language textbooks, there is "Is this a pen?" question which is not only useless and meaningless but also unnecessary and inappropriate. If you show a pen and ask this question to somebody in the streets of London, he would probably take it as provocation or insulting question. On the other hand, Macbeth's famous line "Is this a dagger which I see before me?" is different from "Is this a pen?" in terms of feelings. Macbeth asks this question, yet he knows the answer and does not want to believe it (Maley \& Duff, 1978). Furthermore, if we look at course book characters like "Mr. Brown ", we can realize that he is different from all humanity, since people in course books don't forget what they want to say, hesitate, make grammatical mistakes, talk nonsense, gossip, make unfunny jokes and fail to understand other people. In other words, they are not real, but real people from everyday life do all of these things. These kinds of artificial dialogues, characters and situations make students bored and unwilling to learn. Literature works help to use language in a meaningful context and more real life like situations. Because characters in literary text are from real life, they can lose their temper, tell long jokes or even swear mildly. Therefore, integrating literature into language class can get students' attraction and make them motivated and willing to learning. Using literature is also beneficial for improving students' vocabulary levels since they learn a word in a real-life like context which increases the recall of the words. (Note 1) 


\section{Literature Review}

In the following sections, the place of literature in the history of language teaching, reasons for the use of literature in language classes will be explained. Additionally, some research studies about the use of literature and students' attitudes towards it will be reviewed.

\subsection{The Place of Literature in Language Teaching}

Language teaching has a long history which has witnessed many changes through the time. Although English was the most preferred and studied language until the sixteenth century, Latin was the popular language of Europe. It was the language of education, commerce, religion, and government in the western world. However, in the sixteenth century, French, Italian and English gained importance because of the political changes in Europe. When modern languages entered curriculum, the way of studying Latin became the standard way of learning languages. Latin was taught in grammar schools through a detailed analysis of grammatical rules. The major focus is on reading and writing skills. Vocabulary was taught via dictionary memorization and translation was the central technique. This standard way of learning a foreign language was Grammar Translation Method (GTM). GTM was called the Classical Method because it was used to teach classical languages like Latin or Greek. A basic principle of GTM was that "learning a foreign language begins with parallel statements in native language" (Demirel, 2003, p. 38). One of the fundamental purposes of GTM was to read literary works in the target language as it was believed that literary language developed students' intellectual abilities. Also by a concentration on literary works, it was assumed that "if the students were continually exposed to the best uses of the English language, it would in some sense "rub off" on their own performance in the language" (Short \& Candlin, 2000, p. 91). Since GTM gave no importance to speaking and oral communication in the late nineteenth century, some changes came out in language teaching. Challenges towards GTM led to literature being pushed aside. However, in late 1980s, a rediscovery of literature was seen in language classrooms. Linguists and English Language teaching (ELT) scholars such as Widdowson (1984), Brumfit (1985), Collie \& Slater (1987), Maley \& Duff (1989), Long \& Carter (1991), Lazar (1993) have emphasized the benefits of using literature in language classrooms. These scholars and linguists have tried to put emphasis on literature as being an important part of the language teaching as well.

\subsection{Reasons for the Use of Literature in Language Classrooms}

In today's multicultural world, there is a strong demand for English as a language of international communication. In this respect, some important reforms in English teaching can be observed as; giving much more attention to literature. Probably, if the works of literature were of no use to interpret and deal with the world of reality, there would be no need to spend time on them. However, literary works have a tie with the problems of reality and which makes them significant in education. The use of literature in language classrooms as a teaching technique helps students to improve basic language skills and areas. According to Collie and Slater (1990), there exist four main reasons which explains the usefulness of literature. These reasons are being a valuable authentic material, cultural enrichment, language enrichment and personal involvement. For being a valuable authentic material, Collie and Slater asserts literature as an "authentic" material. To make the meaning of authentic material clear, Nunan (1989) mentions "any material which has not been specifically produced for the purpose of language teaching". Literary works are not written for the sake of teaching a language. Just like a magazine paper, cartoons or newspaper articles, literature gives real examples of language. In literary works, we can find more real-life like narratives than we can find in puesedo narratives in course book (Lazar, 1993). In literary texts, we can find something about "fundamental human issues". For example, in the plays of Shakespeare, we can enjoy the seventeenth century's issues in human lives. Therefore, it can be said that the meaning given in the literary works "transcend through centuries". For cultural enrichment, while learning a new language, learning the culture in which the target language has nourished is also important because the use of the language has given their shape through the culture. Also, many language learners are advised to visit the country where the language is spoken (Collie \& Slater, 1990). Surely, we can find the culture of the target language in the works of literature. The setting or the characters' background offers the learners a panoromic view about the culture. For example, while reading E. Hemingway's or F. Scott Fitzgerald's works, we can discover the decay of American Dream in 1920s. Learners can discover the "customs, possessions, fears, feelings, thoughts" of the people who live in that culture which is benefical to deepen their perspectives. Learners also explore how the native speakers of the target language speak in the literary texts. Overall, as Collie and Slater stated, "Literature is perhaps best seen as a complement to other materials used to increase the foreign learners' insight into the country whose language is being learnt" (Collie \& Slater, 1990, p.4). For being language enrichment, literature offers sometimes "different from other forms of discourse in that it breaks the more usual rules of syntax, collocation and even cohesion" (Lazar, 1993, p.18) because it is not written for the sake of teaching a language. Learners may not find a common daily life language, but what they find is of course right. By reading literature, learners are exposed to the functions of the written language (Collie \& Slater, 1990). Learners start to know the function and formulation of the target language. As it is stated by Lazar, using literature with students can help them to become more sensitive to some of the overall features of English. Also, literary works help to improve oral skills of the students (Collie \& Slater, 1990). By summarizing a chapter or depicting a character, students' oral skills develop strongly. Moreover, intermediate or advanced learners' understanding of the language extend deeply. As it is stated before, literary works may have elaborate language - figurative language - which helps to appreciate and enjoy the literary works. For personal involvement, if students are accustomed to reading works of literature in their own language, they surely will motivate to read in the target language because literature composes a valuable part in the cultures. As stated by Collie and Slater, "Literature can be helpful in the language learning process because of the 
personal involvement it fosters in readers" (Collie \& Slater, 1990, p. 5). By reading a literary text, the student "begins to inhabit the text". A character, a theme or even the time of the literary work may interest the students. They are drawn into the book. Comprehending the lexical words or phrases becomes less significant than pursing the development of the story. The students feel and share some emotions with certain characters. This is useful in whole language learning process since a motivated student via literature feels a relationship with the text and himself or herself.

As explained by many researchers, academics and educationalists, integrating literature into EFL classes has a lot of benefits. While learning a language, it is important to expose learners to both written and spoken activities in the target language and literature supplies this exposure since everything is meaningful and contextualized in literary works. So, it is easy for learners to acquire the ability of the new language by using literature. Also, the tasks or activites related with literary texts may stimulate learners' acquisition skills. By doing a task or activity alone, learners absorb the use of language (Lazar, 1993, p. 18). Literature is motivating material since it "exposes students to complex themes and fresh, unexpected usages of language" (Lazar, 1993, p. 15). It is also authentic material because we can find real life situations in literary texts. Literature also develops students' interpretive abilities. As we know that almost every literary text has at least a theme. While learning a new language, learners are exposed to interpret or form hypotheses from the texts. Therefore, literary works are bountiful source for improving learners' skills to "infer meaning or make interpretations" (Lazar, 1993, p. 19).

\subsection{Some Studies about the Use of Literature in Language Classes and Students' Attitudes Towards Literature}

By reviewing the related literature of the present study, it is important to clear the number of studies related to the use of literature in language classes and student' attitudes towards it with the effects of literature on vocabulary learning. As far as we searched, studies and theses conducted in the world and in Turkey will be given in the following section:

In a study conducted by Ghazali, Setia, Muthusamy and Jusoff (2009), the attitudes of students' towards the literary texts and what kind of texts they prefer to read were investigated in Malaysia. As conclusion of their study, it was found that short story was the most popular type of literary text among students but poem and novel were not popular among students. In a study conducted by Phat (2013), students' opinions towards literature were searched with participation of 234 at a university in Ho Chi Minh City. It was found that most of the students approved the benefits of literature in speaking skill. $154(65,81 \%)$ students agreed that literature improved their speaking -communication- skills.

In a study conducted by Akyel and Yalçın (1990), the specific contributions of drama, poetry and prose fiction in developing EFL senior high school students' competence in language and literature was researched. The study revealed that students regarded "novel" as the most effective way in developing language skills and cultural awareness, and "drama" as the most effective way of developing oral expressions. In another study carried out by Özkeçeci (1994), the relationships between the study of the literature and language teaching in university preparatory classes was investigated. At the end of the study, a significant difference was found between the opinions of the students and instructors which originated from the difference in their departments they studied. In a study conducted by Gebenliler (2006), the opinions of university preparatory students on the use of drama techniques and determination of their level of language use and self-confidence were investigated. The results pointed that the students' level of language use and self-confidence levels increased positively after the use drama scripts. Similarly, the views of EFL students towards literature in ELT department was investigated by Gölgeli (2006). The results of the Gölgeli's study revealed that there was a correlation between students' perceived language proficiency levels, personal taste in reading, reading motivations and views about literature classes in English. Likewise, a study conducted by Doğrul (2007) researched the role of children's literature -specially short stories- on success in vocabulary teaching. The results of the study showed that using stories from children literature had positive effects on developing success in language teaching. Another study which was conducted by Demircioğlu (2008) searched private primary school students' attitudes towards learning new vocabulary items through drama. The results of Demircioğlu's study indicated that young learners' communication skills improved, their long-term retention of vocabulary promoted and they got motivated via drama integrated lesson plans. Similarly, a study conducted by Ziya (2009), searched the vocabulary competence of 5th grade students by integrating different genres of literature. At the end of the study it was found that integration of literature into English courses had a positive effect on the enhancement of vocabulary competence. Likewise, Köylüoğlu (2010) investigated the use of drama techniques in grammar teaching. Throughout the study, it was researched the teaching of grammar (simple present tense) via drama among high school students. The results of Köylüoğlu's study revealed that teaching grammar with drama led to beter results than teaching with traditional methods.

\section{Statement of the Problem}

Many researchers, scientists and language teachers have accepted that literature has several contributions to learning and teaching a foreign language. Infusing literature into the curriculum helps students in the skills of reading, writing, listening and speaking (Moody, 1971). There are many significant reasons why a language teacher should benefit from literature in the classroom. First of all, literature is an "authentic" material. A piece of literature is not composed for the sake of teaching the language. So, many texts are given in real-life context. Secondly, literature is a complement to other materials used to increase the foreign learner's insight into the country whose language is being learnt (Collie \& Slater, 1987). By reading literature pieces, a person can understand the culture, traditions and customs of that country where the target language is spoken. Thirdly, literature provides language enrichment for many individual lexical or syntactic items. Literature includes some slangs, proverbs of the target language that learner may not see anywhere else. Texts give the opportunity to face with these linguistic and language enrichment to the learner. Lastly, reading a literary text gives the opportunity to learners to get into the text. S/he "begins to inhabit the text" (Collie \& Slater, 1987, p. 6). 
In spite of these benefits, many language teachers seem to be content with the text books. Unfortunately, many language teachers just ask their students to read the texts in the course books. Students want to learn a language in real-life situation, on the other hand text book passages do not provide this. Due to this deficiency, this present paper is prompted to "re-highlight" the benefits of literature in language classes and its effect on vocabulary learning and also remind language teachers about the use of literature "consciously" in classes.

\section{Significance of the Problem}

According to the literature, very few studies have been conducted so far related with the use of literature in language classrooms. Moreover, as far as we researched, some researchers only gave importance to the benefits of some literature genres such as poetry not by giving importance to students' attitudes towards the use of literature in lessons. For these reasons, this paper can be helpful.

Firstly, the findings of this paper can be useful for syllabus designers and material writers becoming aware of the benefits of using literature in language classrooms. Secondly, for language teachers becoming aware of the effects of literature on vocabulary learning levels of the students. Finally, for language teachers and syllabus designers adding "consciously" appropriate literature texts into the lessons.

\section{Research Questions of the Study}

As it is stated above, the aim of this research is to "re-highlight" the benefits of using literature in language classrooms especially in vocabulary learning and make teachers "consciously" use it as a resource in language classes. In this study, our assumptions are based on the following research questions which are formulated by the researcher:

1. What are the attitudes of English learners towards literature especially theatrical plays?

2. Does literature i.e. the usage of drama scripts have any effects on vocabulary proficiency levels of foreign language learners?

\section{Method}

\subsection{Subjects}

The participants of this study were 14 A2 English Language level students who willingly enrolled in a private language school to learn English. 9 of them were female learners and 5 of them were male learners. They were adult learners whose ages ranged from 20 to 24 . They graduated from different high schools and they were undergraduate students in different departments at a state university in Turkey.

\subsection{Instruments}

The instruments of this study were an attitude questionnaire (Appendix 1), a vocabulary test (Appendix 2) and five different lesson plans (Appendix 3). The first one was designed to find out the participants' attitudes towards the use of literature, especially drama scripts in language classrooms. This attitude questionnaire had 2 parts. In the first part of it, there were questions about the participants' personal information. The second part of the attitude questionnaire was made up of expressions concerned with the participants' attitudes towards the using literature, especially drama scripts in the language classes. There were 10 expressions. Both parts were subjective but the second part showed self assessment of the participants' attitudes.

The second instrument of this research was a vocabulary test. This vocabulary test was made of words that were both mentioned in the course book of the private language school and in the literary texts which the researcher chose. This vocabulary test had different parts such as matching, testing, finding words, etc. This vocabulary test aimed to figure out the differences of participants' vocabulary levels before and after the application of the five different lesson plans.

The last instruments of this study were five different lesson plans which were used during this research. These lesson plans were literature integrated lesson plans taken from the book of "English Sketches". The materials for these lesson plans were designed by the researcher herself. "The Lost Property Office", "The Superlative Vacuum Cleaner", "Mr. Universe", "Shakespeare's House" and "A Ticket to Birmingham" were the names of the drama scripts. These lesson plans were conducted in different weeks in a lesson hour which was about 40 or 45 minutes.

\subsection{Procedures}

Data collection of this research was twofold as descriptive and experimental. The descriptive part was made of an attitude questionnaire towards using literature, namely drama, in language classrooms. The attitude questionnaire was made up of 2 parts. The first part gave information about students' personal information. These questions provided the researcher with information about the participants. The second part of the attitude questionnaire was made up of 10 items with 5 point Likert Scale. The attitude questionnaire required students to tick only one box according to their beliefs. The participants' indication levels of agreement were given with these statements. The researcher entered and analysed the data to the computer as the following: "strongly agree:5, agree:4, undecided:3, disagree:2, strongly disagree:1". The results of the attitude questionnaire were obtained through SPSS analysis programme.

The experimental part was conducted in a ten-week period. In the first week of the study, the attitude questionnaire, the vocabulary test and 5 sample lesson plans were prepared. While preparing them, validity and reliability criteria were taken into the consideration as well. In the second week of the study, to determine the validity of the attitude questionnaire and the vocabulary test, the principles of face validity and content validity were carried out. In this study, to determine the face validity and content validity of the instruments, they were presented to three experts. These three 
experts concerned with the items that were asked in the attitude questionnaire and the vocabulary test. Two items of the attitude questionnaire and five items of the vocabulary test were found unnecessary and inappropriate by them. Therefore, with their criticism and suggestions some of items were deleted. Moreover, to specify the reliability of the attitude questionnaire and the vocabulary test, the criteria of inter-rater reliability were performed. To figure out the inter-rater reliability of the instruments which were used in this study, five colleagues rated. These five colleagues subjectively judged the adequacy of the attitude questionnaire and the vocabulary test and gave consistent results. Having constructed the attitude questionnaire and the vocabulary test, the researcher performed a pilot study with the participation of 20 students who were similar to the students in this present study, in other private language school in Turkey. Internal consistency was checked through calculating Cronbach's Alpha which was found (.828). In the third week of the study two groups were chosen randomly and labeled as the experimental group and the control group. The numbers of the both groups were the same as one experimental group with 7 students and one control group with the same number. Then, the attitude questionnaire and the vocabulary test were administered to both groups and their results were entered to SPSS programme. In the fourth, fifth, sixth, seventh and eighth weeks of the study, the sample lesson plans were conducted. The researcher continued her regular curriculum with both the control group and the experimental group. However, she applied literature integrated lesson plans to the experimental group. 5 different lesson plans were carried out. Namely, 7 of these students had the lessons of the traditional curriculum of the private language school (the control group), while the other 7 of them -plus to the traditional curriculum- had the literature especially theatrical plays integrated lessons (the experimental group). In the ninth week of the research, the researcher once again conducted the attitude questionnaire and the vocabulary test to both the experimental group and the control group and entered the results to SPSS programme. In the last week of the study, all the results obtained from the attitude questionnaires and vocabulary tests were analyzed and compared by SPSS programme. Thereafter, the results were compared in the following part. To find out the attitudes of students towards literature, especially theatrical plays, Wilcoxon Signed Rank Test was carried out. Since the existing number and the statements of questionnaire were not appropriate for the t-test, Mann-Whitney Rank Test was utilized to examine the different levels of vocabulary learning levels. In all attitude questionnaires and vocabulary tests, positive and significant results were found. Overall, students had positive attitudes towards the use of literature -theatrical plays- in language classrooms and using appropriate literary works helped students to increase their vocabulary proficiency levels.

\section{Results}

\subsection{The Wilcoxon Signed Rank Test for the Attitude Questionnaire}

In this research, there are two groups as one experimental group with 7 students and one control group with the same number of participants. 7 of these students had the lessons of the traditional curriculum of the private language school (control group) while the other 7 of them -plus to the traditional curriculum- had the literature especially theatrical plays integrated lessons (experimental group). In this study, it is compared whether there is a difference between experimental and control groups in their attitudes towards literature integrated lessons. Due to this reason a 10 items attitude questionnaire with 5 point Likert Scale is given the participants and asked them to rate their views. To investigate the differences in participants' attitudes The Wilcoxon Signed Ranks Test is used. Students' attitudes towards literature integrated lessons are shown in table 7.1.

Table 7.1. The Wilcoxon Signed Rank Test For the Attitude Questionnaire

\begin{tabular}{lllll}
\hline & & N & Mean Rank & Sum of Ranks \\
\hline Post test - pre test & Negative Ranks & $12^{\mathrm{a}}$ & 7,54 & 90,50 \\
& Positive Ranks & $2^{\mathrm{b}}$ & 7,25 & 14,40 \\
& Ties & $0^{\mathrm{c}}$ & & \\
& Total & 14 & & \\
\hline
\end{tabular}
a. post test $<$ pre test
b. post test $>$ pre test
c. post test $=$ pre test

In this table, the finding was composed of an attitude questionnaire (Appendix 1) which had 10 items. With this 10 item attitude questionnaire, students' attitudes towards literature integrated lessons were investigated. It was observed that the degree of participation increased for the answers of items. To put it differently, before the treatment of literature integrated lesson plans into the traditional curriculum, some of the students marked "disagree", after the treatment they marked "agree". According to the values in table, while 12 students marked "agree", 2 students marked "disagree". There was no student who changed his / her mind before and after the treatment of the literature integrated lessons plans. 
Table 7.2. Test Statistics ${ }^{b}$ for the Wilcoxon Signed Rank Tests

\begin{tabular}{ll}
\hline Post test - pre test & \\
\hline $\mathrm{Z}$ & $-2,387^{\mathrm{a}}$ \\
Asymp.Sig.(2-tailed) &, 017
\end{tabular}

a. Based on positive ranks.

b. Wilcoxon Signed Ranks Test

According to the table 7.2 the significance level is $p=0,017<p=0,05$. In this case, we can infer from the table that, the differences between pre and post treatments of the literature integrated lessons are statistically significant. This result comes to the light through students' subjective attitudes $(\mathrm{p}=0,017<0,05 ; \mathrm{z}=2,387)$. This conclusion can be interpreted as; learning with traditional curriculum and literature integrated curriculum make a difference in students' attitudes in language teaching especially in ELT.

\subsection{Descriptive Statistics}

In this research, to find out the participants' success -vocabulary-learning levels- descriptive frequency ranges are analyzed. The subjects had scores from the vocabulary test, which both conducted pre and post application of the literature integrated lesson plans.

Table 7.3. Descriptive Statistics For the Vocabulary Test

\begin{tabular}{llllll}
\hline & N & Minimum & Maximum & Mean & Std. Deviation \\
\hline voc1 ( pre ) & 14 & 23 & 84 & 44,71 & 17,340 \\
$\operatorname{voc}$ 2 ( post ) & 14 & 31 & 100 & 68,36 & 22,404 \\
Valid N (listwise) & 14 & & & & \\
\hline
\end{tabular}

It can be understood from the table 7.3 that, a very important increase in the score mean was seen. Before the treatment of the five different sample scripts, students' score mean was $M=44,71$ while after the treatment score mean was $\mathrm{M}=68,36$. Overall, it can be said that, the students in the experimental group seem to be more successful in vocabulary learning than those in the control group because of literature integrated lesson plans.

\subsection{Mann - Whitney Test for the Vocabulary Test}

In this research, the main investigation is to find out whether there is a difference between control and experimental groups in their vocabulary learning levels. For that reason, a vocabulary test (Appendix 2) is applied. Students' scores are compared by taking consideration of control and experimental groups. To investigate the relation between the findings Mann - Whitney Test is used.

Table 7.4. Mann - Whitney Test for the Vocabulary Test

\begin{tabular}{llccc}
\hline \multicolumn{1}{c}{ Group } & & N & Mean Rank & Sum of Ranks \\
\hline Pre application & Experimental & 7 & 6,71 & 47,00 \\
& Control & 7 & 8,29 & 58,00 \\
& Total & 14 & & \\
\hline Post application & Experimental & 7 & 10,29 & 72,00 \\
& Control & 7 & 4,71 & 33,00
\end{tabular}

We can figure out from the table that, before the treatment of literature integrated lesson plans to the experimental group, the control groups' mean is higher than the experiment group $(M=8,29)$. Although, when we look at the second part of the table, which shows the results after the treatment of literature integrated lesson plans, we can see the mean of the experiment group outperformed the control group $(\mathrm{M}=10,29)$. Students in the experimental group appear more successful in vocabulary learning proficiencies because of literature integrated lessons. This means that, the treatment of literature integrated lessons to the experiment group seem much more successful than the application of the traditional curriculum to the control group. 
Table 7.5. Test Statisticsb for the MannWhitney and Wilcoxon Signed Rank Tests

\begin{tabular}{lcc}
\hline & voc1(pre) & voc2(post) \\
\hline Mann-Whitney U & 19,000 & 5,000 \\
Wilcoxon W & 47,000 & 33,000 \\
Z &,- 706 & $-2,505$ \\
Asymp. Sig. (2-tailed) &, 480 &, 012 \\
ExactSig.[2*(1-tailedSig.)] &, $535^{\mathrm{a}}$ &, $011^{\mathrm{a}}$ \\
\hline
\end{tabular}

a. Not corrected for ties.

b. Grouping Variable: group

When we examined the table, before the treatment of literature especially drama integrated lesson plans there was insignificant relation between the vocabulary levels of the students, while after the treatment there is a significant relation between the vocabulary levels of the students (Pre application; $p=0,480>0,05 ; z=0,706$ Post application; $p$ $=0,011<0,05 ; \mathrm{z}=2,505)$. This result is interpreted as; there is a statistically insignificant relation between the pre treatment of literature integrated lesson plans and participants' exam scores, but there is a statistically significant relation between the post treatment of literature integrated lesson plans and participants' exam scores. To investigate this situation in a more detailed way, Wilcoxon Signed Rank Test is used by examining each group's success.

\subsection{The Wilcoxon Signed Rank Test For Experimental Group's Vocabulary Test}

In table 7.6, the exam scores of the experiment group participants', who had literature integrated lessons, were compared before and after the treatment of literature integrated lesson plans.

Table 7.6. The Wilcoxon Signed Rank Test For the Vocabulary Test of the Experiment Group

\begin{tabular}{lllll}
\hline & $\mathrm{N}$ & Mean Rank & Sum of Ranks \\
\hline voc2 - voc1 & Negative Ranks & $0^{\mathrm{a}}$ &, 00 &, 00 \\
& Positive Ranks & $7^{\mathrm{b}}$ & 4,00 & 28,00 \\
& Ties & $0^{\mathrm{c}}$ & & \\
& Total & 7 & & \\
\hline
\end{tabular}
a. $\operatorname{voc} 2<\operatorname{voc} 1$
b. $\operatorname{voc} 2>\operatorname{voc} 1$
c. $\operatorname{voc} 2=\operatorname{voc} 1$

It can be inferred from the table 7.6 that, for each student much higher scores are observed after the treatment of literature integrated lesson plans. Therefore, it can be said that each students learning English with the help of literature integrated lesson plans achieved success.

Table 7.7. Test Statistics ${ }^{\mathrm{b}}$ For The Wilcoxon Signed Ranks Test

\begin{tabular}{lc}
\hline & voc2 - voc1 \\
\hline$Z$ & $-2,375^{\mathrm{a}}$ \\
Asymp. Sig. (2-tailed) &, 018 \\
\hline
\end{tabular}

a.Based on negative ranks.

b. Wilcoxon Signed Ranks Test

Table 7.7 gives us information about whether the differences between variables include a real relation or not. It demonstrates that the relationship between the findings is statistically significant $(p=0,018<0,05 ; z=2,375)$. This result can be interpreted as; literature integrated lesson plans have an effect on the students' success.

\section{Discussion and Conclusion}

Many researchers in the field of ELT and linguists have emphasized the use of literature in language classes by explaining its benefits. They have argued that literature is an authentic material because of the fact that it is not written for the sake of teaching a language. Lazar (1993) summarizes the reasons for using literature in language classrooms as its being very motivating and stimulus for language acquisition, helping students to understand another culture, developing students' interpretative abilities, expanding students' language awareness and encouraging students to talk about their opinions and feelings. Moreover, literature can help students to develop personal enrichment, language development and cultural enrichment as stated by many researchers such as Collie \& Slater (1987), Lazar (1993), Carter $\&$ Brumfit (2000). Many language teachers have already been aware of these advantages of using literature in their classes, unfortunately, practically they do not use it "consciously" in their classes. 
In our study, contrary to the mentioned teachers' attitudes towards the use of literature, students recognize that "appropriate theatrical plays should be included in the course books" (the last item of the attitude questionnaire). Before the treatment, $7,1 \%$ of the students agreed as the above mentioned item. After the treatment phase, 57,1\% of the students agreed that "appropriate theatrical plays should be included in the course books". There is a common idea that students don't like literature and don't want to study it. Although in a study conducted by Hirvela and Boyle (1988), it was found that students fear of literature because of their insufficient literature background. In addition to this, Collie \& Slater states that "as long as the reader is well-motivated, and as long as the experience of engaging with literature is kept sufficiently interesting, varied and non-directive to let the reader feel that he or she is taking possession of a previously unknown territory" (Collie \& Slater,1987, p.6). As a result of our study, it can be said that students are not pleased with traditional curriculum and textbooks and that they want to study literary texts. That is, learning with traditional curriculum and literature integrated lesson plans make an important difference in students' attitudes towards ELT.

Another important outcome of this study is that, students' thinking literary integrated language classes improve their speaking $(78,5 \%)$, reading $(71,3 \%)$, writing $(64,2 \%)$, listening $(78,5 \%)$ skills and grammar knowledge $(57 \%)$ relating the items in order of $2^{\text {nd }}, 3^{\text {rd }}, 4^{\text {th }}, 5^{\text {th }}, 7^{\text {th }}$. According to Moody (1971), the integration of literature in language teaching curriculum helps to students to improve their speaking, reading, writing and listening skills. Similarly, Parkinson and Reid Thomas (2000) argue that literature provides a good model for writing since it is memorable, non-trivial and challenging.

Similarly, students agreed that literature integrated lessons develop their critical thinking $(71,3 \%)$ and creative thinking $(64,2 \%)$ abilities relating the items respectively $8^{\text {th }}$ and $9^{\text {th }}$, as well. According to Yaesmin, Azad and Ferdoush (2011) literature simultaneously encourages students' imagination and critical thinking. Engaging imaginatively with literature students begins to "inhabit the text". This technique "can have more beneficial effects upon the whole language learning process" (Collie \& Slater,1987, p.6). It can be claimed that the attitudes of students towards literature, especially theatrical plays have been affected positively and have increased the impact of the use of literary texts.

As another crucial outcome of this study, after the treatment phase, the students recognize that appropriate theatrical plays are useful in improving their foreign language vocabulary treasure. There is an item which investigates the students' attitudes about improving vocabulary levels through theatrical plays $\left(6^{\text {th }}\right.$ item). Traditionally, in language teaching, vocabulary takes less importance than the other aspects of the language as a communication system. There is a common idea that grammar should be taught first but in time learners would acquire vocabulary (Chacón-Beltrán, Abelló-Contesse \& Torreblanca-López, 2010). Before the treatment phase, 78,5\% of the students agreed the item mentioned above. The students were aware of the benefits of theatrical plays in vocabulary learning levels. Additionally, after the treatment phase, this number increased because $85,7 \%$ of the students agreed the $6^{\text {th }}$ item. As observed by Povey (1972) "literature will increase all language skills because literature will extend linguistic knowledge by giving evidence of extensive and subtle vocabulary usage, and complex and exact syntax" (cited in McKay 1982, p.529). It can be said that the students consider the benefits of literature in language classes, especially in vocabulary learning.

All in all, the findings of this study seem to confirm the importance of literature in language classes which are explained by linguists and scholars. As far as we observed in the private language school that the study conducted and in Turkey in general, most of language teachers are aware of the benefits of using literature in classes but somehow they slide over it slightly. Showalter (2003) calls this situation "anxiety of teaching" literature. She continues as "teaching literature feels especially unsettling" (Showalter, 2003, p.3). Teaching literature is like the externalization of our personality and perceptions. It is "unsettling" because language teachers are probably not confident about their authority. These reasons withhold language teachers using literature "consciously" in their classes despite the fact that the benefits of it are known by them theoretically. Finally, this study can be beneficial for language teachers, syllabus designers and textbook writers to integrate literary texts into classes.

\section{References}

Akyel, A. \& Yalçin, E. (1990). Literature in the EFL Class : A study of goal-achievement incongruence. ELT Journal 44/3, 174-180. Retrieved from: http://203.72.145.166/ELT/files/44-3-1.pdf

Brumfit, C. J. \& Carter R. A. (1986). Literature and Language Teaching. Oxford University Press

Carter, R. \& Long, M. (1991). Teaching Literature. Longman Publishing

Case, D. \& Wilson, K. (1995). English Sketches by the English Teaching Theatre, books 1 \& 2. Macmillan Publishers Ltd

Chacón-Beltrán, R. \& Abelló-Contesse, C. \& Torreblanca-López, M. M. (2010). Insights Into Non-native Vocabulary Teaching and Learning. British Cataloging in Publication Data

Collie, J. \& Slater, S. (1987). Literature in the Language Classroom: A Resource Book of Ideas and Activities. Cambridge University Press

Demircioğlu, Ş. (2008). Teaching English Vocabulary to Young Learners via Drama (Master's thesis). Retrieved from http://tez2.yok.gov.tr/ 
Demirel, Ö. (2003). ELT Methodology. Pegem A Publication

Duff, A. \& Maley, A. (2007). Literature : Resource Books for Teachers. Oxford University Press

Gebenliler, H. E. (2006). The Effect of Script as a Drama Technique on Self-confidence and Language Use (Master's thesis). Retrieved from http://tez2.yok.gov.tr/

Ghazali, S. N., Setia, R., Muthusamy, C. \& Jusoff, K. (2009). "ESL studnets' Attitudes towards Texts and Teaching Methods used in Literature Classes". Canadian Center of Science and Education (ccse) Vol:2, N: 4: 51-56.

Gölgeli, İ. M. (2006). The Views of EFL Studnets Towards Literature in English Language Teaching Department (Master's thesis). Retrieved from http://tez2.yok.gov.tr/

Hirvela, A. \& Boyle, J. (1988). Literature Courses and Students Attitudes. ELT Journal Volume 42/3 July 179-183

Hismanoğlu, M. (2005). Teaching English Through Literature. Journal of Language and Linguistic Studies Vol.1, No.1. 53-66.

Karar Doğrul, S. (2007). Effects of Children's Literature on Success in Vocabulary Teaching (Master's thesis). Retrieved from http://tez2.yok.gov.tr/

Köylüoğlu, N. (2010). Using Drama in Teaching For young Learners (Mater's Thesis). Retrieved from http://tez2.yok.gov.tr/

Lazar, G. (1993). Literature and Language Teaching : A Guide for Teachers and Trainers. Cambridge University Press

Maley, A. \& Duff, A. (1978). Drama techniques in Language Learning: A resource book of Communication Activities For Language Teachers. Cambridge University Press

McKay, S. (1982). "Literature in the ESL Classroom”. TESOL Quarterly Vol. 16. No.4: 529-536.

Moody, H. L. B. (1971). The teaching of Literature With Special Reference to Developing Countries. Longman Publishing

Nunan, D. (1989). Designing Tasks for the Communicative Classroom. Cambridge University Press

Özkeçeci, T. (1994). An Analysis of the Attitudes of the Instructors and Students towards the Use of Literature in English Language Teaching (Master's Thesis). Retrieved from http://tez2.yok.gov.tr/

Parkinson, B. \& Reid Thomas, H. (2000). Teaching Literature in a Second Language. Edinburg University Press

Phat, C. H., (2013, 671-688). The Implementation of Literature in Teaching Speaking for Advanced Students Paper presented at The $3^{\text {rd }}$ International Conference on Foreign Language Learning and Teaching, Retrieved from: http://www.fllt2013.org/

Short, M. H. \& Candlin, C. N. (2000). “Teaching Study Skills For English Literature.” In Literature and Language Teaching. Eds. C.J. Brumfit \& R.A. Carter (89-109). Oxford University Press

Showalter, E. (2003). Teaching Literature Blackwell Publishing

Turker, F. (1991). Using "Literature" in Language Teaching. Hacettepe University Education Faculty Journal Vol. 6. 299-305

Widdowson, H.G. (1984). Aspects of Language Teaching. Oxford University Press

Yaesmin, N., Azad, A.K. \& Ferdoush, J. (2011). Teaching Language through Literature: Designing Appropriate Classroom Activities. ASA University Review, Vol. 5 No. 2, July-December 283-297

Ziya, S. (2009). Efficiency of Literature-Integrated Approach on Vocabulary Competence (Master's Thesis). Retrieved from http://tez2.yok.gov.tr/

\section{Notes}

Note 1. Derived from the Author's M.A thesis. Elif KARAKAYA 


\begin{tabular}{|c|c|c|c|c|c|}
\hline & 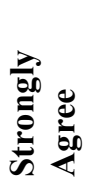 & 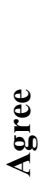 & 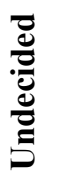 & 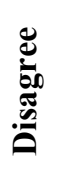 & 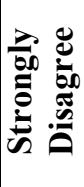 \\
\hline 1. I enjoy reading theatrical plays in English. & O & ० & o & 0 & 0 \\
\hline 2. Studying appropriate theatrical plays improves my speaking skills. & ○ & ○ & ○ & o & ○ \\
\hline 3. Studying appropriate theatrical plays improves my reading skills. & O & ○ & ○ & ○ & ० \\
\hline 4. Studying appropriate theatrical plays improves my writing skills. & O & O & ○ & O & ○ \\
\hline 5. Studying appropriate theatrical plays improves my listening skills. & O & ० & O & O & o \\
\hline $\begin{array}{l}\text { 6. Studying appropriate theatrical plays improves my vocabulary } \\
\text { knowledge. }\end{array}$ & 0 & 0 & 0 & 0 & O \\
\hline $\begin{array}{l}\text { 7. Studying appropriate theatrical plays improves my grammar } \\
\text { knowledge. }\end{array}$ & 0 & 0 & ○ & ○ & 0 \\
\hline 8. Studying appropriate theatrical plays improves my critical thinking. & O & ○ & ○ & ○ & ○ \\
\hline 9. Studying appropriate theatrical plays improves my creative thinking. & ○ & ○ & ○ & O & ○ \\
\hline 10. Appropriate theatrical plays should be in the course books. & 0 & 0 & 0 & 0 & 0 \\
\hline
\end{tabular}

A) Choose the correct words according to the sentences.

1) I still keep my mothers of jewelry box.
a) souvenir
b) calender
c) recorder
d) pretty

2) In hotels door,we can see a sing of "Don't
a) irritate
b) sleep
c) disturb
d) talk

3) There is a ................ between two football teams.
a) hate
b) competition
c) exam
d) love

4) She football ( in negative meaning )
a) enjoy
b) love
c) like
d) detest

5) I was reading a magazine when the door
a) handle
b) way
c) bell
d) lock rang.

\section{B) Find the mixed words in the below}

sensationalrevolutionaryridiculousprobablyambitionincredibleexactly

\section{C) Choose the correct words that are suitable for definitions}

1) means that there is no hair.
a) blonde
b) bald
c) moustache
d) beard
2) means that you can put your cigarette on it.
a) pipe
b) bowl
c) pot
d) ashtray

3) means that a person who is a contest.
a) contestant
b) judge
c) race
d) team

4) means that a person who works in a court.
a) law
b) judge
c) civil
d) president 
D) Match the words in coloum -A- with coloum -B-

A

pick

fall

dust

lost property

make

count

lucky
B

furniture

money

up

day

asleep

decision

Office

E) Match the words with the pictures.
a) Kilt
b) Sponge
c) Circus
d) Typewriter
e) Bucket
f) Seat
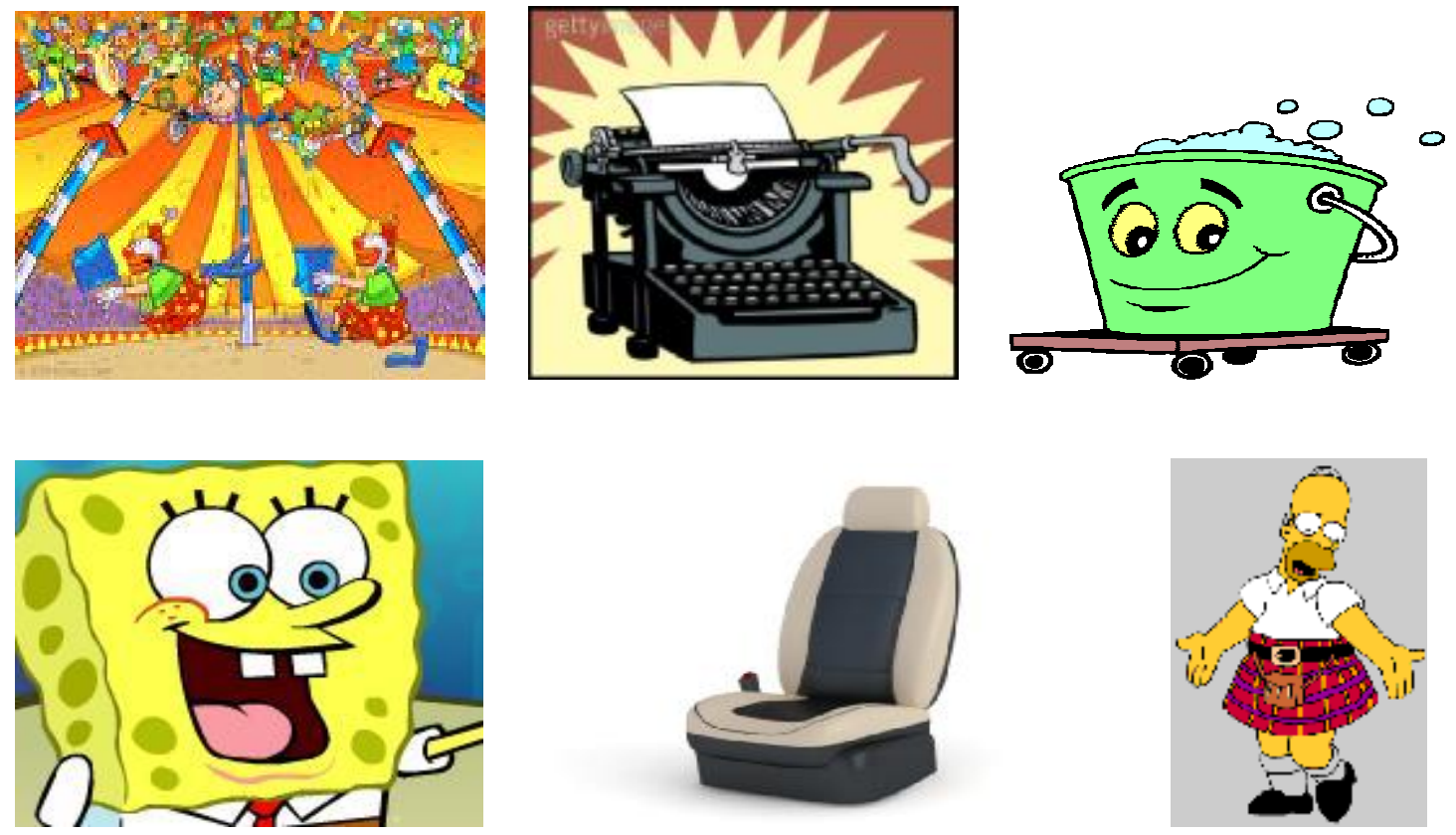

\section{Appendix 3}

\section{Sample Lesson Plan}

\section{SHAKESPEARE'S HOUSE}

The script is called "Shakespeare's house". The script is performed in 1974. The script is taken from the book " English Sketches, Sketches from the English Teaching Theatre Intermediate Book 2 ”. Doug Case and Ken Wilson are the writers of the book. The book is composed of 32 scripts which are appropriate for English language learners.

Here is the lesson plan.

Class : A2 Level

Topic : Talking about famous people

Date : May 10th, 2011

Objectives : To have the students learn and use new vocabulary introduced in the lesson.

Materials : Pictures, computer, speakers, CDs, worksheets, handouts. 


\section{Activities}

Warm-up Activities ( 15 minutes ):Firstly, the teacher hangs a portrait of Shakespeare on the board and asks her students to guess the person. Secondly, the teacher hands out a brief biography of Shakespeare. Lastly, the teacher gives out a quiz about Shakespeare's life to figure out that the students understood the text or not .

Handing-out the scripts : The teacher gives out the script "Sketch 13 " from the "English Script" book.

Listening ( 5 minutes ): The students listen to the script which is given with the book. It has got an important advantage that the scripts are read by native speakers which will help students to understand the target language in a better way. The script is listened to once.

Comprehension ( 5 minutes ): The teacher asks some questions about the text in order to control whether the students have understood or not. There are some example questions. The expected answers are in the parentheses.

Where are the two people? ( They suppose that they are in the Shakespeare's house but actually they are in the wrong house )

Who are Ethel and Sidney? ( They are tourists.)

Who makes not true deductions? (Ethel is the one who makes wrong deductions. )

What things did they see at the house ? (Armchair, typewriter, television, Shakespeare's grandson, ashtray. )

What did they buy as a souvenir ? ( The ashtray )

How much money did they buy the astray? ( Twenty-five pounds )

Discussion ( 10 minutes ): The teacher asks students some questions to make discussion.

What do they feel if they are in a famous person's house?

What do they feel if the house is wrong?

Language Work ( 15 minutes ): The students firstly read the text by themselves. They try to guess the meaning of unknown words (typewriter, asleep, famous, souvenir, ashtray, disturb). The teacher gives a word search about the unknown words.

Performing the Script ( 10 minutes ): The students read the script from the handouts and the teacher gives feedback about the wrongly pronounced words.

Cultural Information ( 5 minutes ): The teacher talks about the actual house of Shakespeare. She shows some pictures from the house and makes her students to think about the house. Also the teacher gives some examples of new words that are found by Shakespeare. 